\title{
Does Low Gonial Angle Affect the Amount of Bone Loss Around Implant in The Posterior Mandible?
}

\author{
Emrah Dilaver(0000-0003-4522-1424) ${ }^{\alpha}$, Muazzez Suzen(0000-0001-5121-9158) ${ }^{\alpha}$, Kivanc Berke Ak(0000-0002-7623-0473) ${ }^{\alpha}$
}

Sina Uckan(0000-0003-1077-7342) ${ }^{\alpha}$

Selcuk Dent J, 2021; 8: 644-647 (Doi: 10.15311/selcukdentj.743119)

Başvuru Tarihi: 27 Mayıs 2020 Yayına Kabul Tarihi: 09 Eylül 2020

\begin{abstract}
Does Low Gonial Angle Affect the Amount of Bone Loss Around Implant in The Posterior Mandible?

Background: The purpose of this study was to investigate whether there is a role of the low gonial angle on marginal bone resorption around the implants placed in the posterior mandible.

Methods: This retrospective study, including 20 patients with 46 implants followed 36 months were inserted in the mandibular edentulous posterior area. Patients without systemic disease were included in this study. The gonial angle was measured on a panoramic x-ray; Patients with a gonial angle of more than 1250 were classified as high gonial angle, and those with less than 1200 were classified as a low gonial angle group. Mesial and distal marginal bone resorption and implant angulation with the occlusal plane were measured via Image $\mathrm{J}$ software (National Institutes of Health; version 1.5i, USA). Independent samples ttest was used to compare measured variables between high and low gonial angle groups.
\end{abstract}

Results: The mean marginal bone resorption (MBL) was $0.27 \pm 0.16 \mathrm{~mm}$ for the mesial side and $0.27 \pm 0.13 \mathrm{~mm}$ for the distal side in the LGA group. In the HGA group, MBL was $0.77 \pm 0.28 \mathrm{~mm}$ for the mesial side and $0.71 \pm 0.27 \mathrm{~mm}$ for the distal side. There was no statistical significance between HGA and LGA groups regarding marginal bone resorption. However, implant angulation with the occlusal plane was correlated with marginal bone resorption in the HGA group.

Conclusion: The result of this study is that a low gonial angle is not directly a risk factor for marginal bone resorption around the dental implant. However, implants should be placed perpendicular to the occlusal plane as possible in the HGA group.

\section{KEYWORDS}

Gonial angle, Marginal bone resorption, Implant surgery

Dental implants have been used routinely for more than fifty years as a treatment option for the rehabilitation of tooth loss and improving the quality of chewing, speech, and esthetics. According to literature, it is considered a safe and successful procedure.

Crestal bone resorption is a mostly encountered problem for dental implants. After prosthetic rehabilitation, resorption around dental implant continues overtime. ${ }^{1}$ There are many factors effecting

\section{öz}

Düşük Gonial Açı Posterior Mandibuladaki İmplant Etrafındaki Kemik Kaybı Miktarını Etkiler Mi?

Amaç: Bu çalışmanın amacı; posterior mandibulaya yerleştirilen implantların etrafındaki marjinal kemik rezorpsiyonunda, düşük gonial açının bir rolünün olup olmadığının araştırılmasıdır.

Gereç ve Yöntemler: Bu retrospektif çalışmada; 36 aylık takibi olan toplam 20 hastada yapılan 46 implant alt çene posterior dişsiz alana yerleştirildi. Sistemik hastalığı olmayan olgular çalışmaya dahil edildi. Gonial açı panaromik röntgen üzerinde ölçülüp; 1250 den fazla olan hastalar yüksek gonial açı, 1200 den az olanlar ise düşük gonial açı grubu olarak sınıflandırıldı. Mezial, distal marjinal kemik rezorpsiyonu ve implantın okluzal düzlemle olan açılanması Image J yazıımı (National Institutes of Health; sürüm 1.5i, USA) ile ölçüldü. Yüksek (HGA) ve düşük gonial açı grupları (LGA) arasındaki farkı karşılaştırmak için bağımsız gruplar $\mathrm{t}$ testi kullanıldı.

Bulgular: Ortalama marjinal kemik rezorpsiyonu (MBL), düşük gonial açı grubunda; mezial taraf için $0.27 \pm 0.16 \mathrm{~mm}$ ve distal taraf için $0.27 \pm 0.13 \mathrm{~mm}$ idi. Yüksek gonial açı grubunda mezial taraf için $0.77 \pm 0.28 \mathrm{~mm}$ ve distal taraf için $0.71 \pm 0.27 \mathrm{~mm}$ idi. Yüksek ve düşük gonial açı grubu arasında marjinal kemik rezorpsiyonu açısından istatistiksel olarak anlamlı bir fark bulunmadı. Ancak; yüksek gonial açı grubunda; implantın okluzal düzlem ile açılanmasının marjinal kemik rezorpsiyonu ile korele olduğu tespit edildi $(p<0.05)$.

Sonuç: Bu çalışmanın sonucunda, düşük gonial açının implant çevresindeki marjinal kemik rezorpsiyonu açısından doğrudan bir risk faktörü olmadığı görülmüştür. Bununla birlikte; implantlar HGA grubunda mümkün olduğunca oklüzal düzleme dik olarak yerleştirilmelidir.

\section{ANAHTAR KELIMELER}

Gonial açı, Marjinal kemik rezorpsiyonu, İmplant cerrahisi

the bone resorption around the dental implant. Systemic status of the patient, biological width, the surface of the dental implant, obesity, and inflammation around dental implant are the most common factors. ${ }^{1,2}$ Although there is no clear view among the factors that cause marginal bone resorption, infection, and excessive occlusal load and combine theory including surgical, prosthetic, and prosthetic factors are the hypotheses that are emphasized. ${ }^{3,4}$

Occlusal overloading (OO) leads to crestal bone

\footnotetext{
${ }^{\alpha}$ İstanbul Medipol University Faculty of Dentistry, Department of Oral and Maxillofacial Surgery, İstanbul, Turkey
} 
resorption and failure of dental implant5,6. Cantilever prostheses, inappropriate crown to implant ratio, premature occlusal contact, masseter hypertrophy, and bruxism are related with $00^{6-8}$

The relation between high bite force and large masseter muscle volume was reported in the literature..$^{9,10,11}$ In a previous study, the gonial angle was found related to residual ridge resorption in patients having implant-retained overdenture prosthesis. $^{12}$ In our knowledge, there was no study regarding whether there is a relationship between low gonial angle and marginal bone resorption around the dental implant in patients with posterior edentulous posterior mandible.

In this study, we investigated the effect of low gonial angle on bone resorption around the dental implants.

\section{MATERIALS AND METHODS}

This retrospective study was performed at Medipol University, School of Dentistry, Turkey. The patients who were inserted dental implants in the posterior mandible were included in this study.

Inclusion criteria:

- Patients who had undergone dental implant placement in posterior premolar and molar region in mandible without other adjunctive surgical treatments for bone deficiency

- Patients with implant retained fixed prosthetic restoration

- Patients with panoramic radiographs about 36 months after implant insertion

Exclusion criteria:

- Patients who have a tooth to the distal side of the implant

- Patients with crown to implant ratio of more than 1.5

- Patients with Diabetes Mellitus and heavy smokers

- Patients with poor oral hygiene in follow-up periods.

- Patients requiring additional surgeries such as onlay grafting and guided tissue generation for dental implant insertion

The gonial angle of the mandible, mesial and distal marginal bone resorption around dental implant and angulation of dental implant with the occlusal plane were measured on panoramic radiographs using Image J software (National Institutes of Health; version 1.5i, USA) (Figure 1). The software was calibrated using the implant length as a known distance. To determine marginal bone resorption, the linear distance between the implant neck to the coronal bone to implant contact at the mesial and distal aspect was measured for each implant. Patients were later divided into two groups according to gonial angle size, as in a study in the literature. ${ }^{13}$ One is a low gonial angle

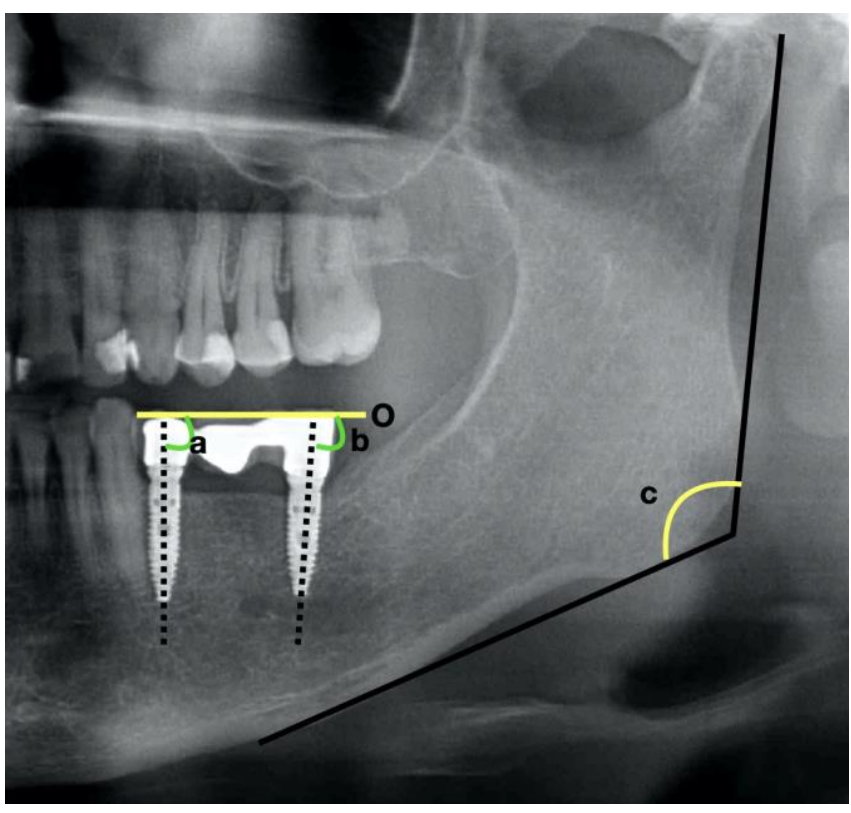

Figure 1

(O) to define the occlusal plane, the reference line was drawn tangent to the cuspid of the crown on implants. $(a, b)$ the angle of the implant's long axis with the occlusal plane was measured using the angle measurement tool, yielding the mesiodistal implant inclination (in degrees). (c) the angle of two lines that are tangential to lower the mandibular body and the posterior border of the mandibular ramus defined as a gonial angle.

a high gonial angle (HGA) group defined as more than 1250 .

\section{Statistical analysis:}

Data were submitted to statistical analyses. Statistical analysis was performed using the Statistical Package for the Social Sciences (SPSS for Windows, version 18.0, SPSS Inc., Chicago, USA). An independent sample t-test was used in the investigation of differences between HGA and LGA. P values < 0.05 were considered as statistically significant.

\section{RESULTS}

After a mean follow-up of 36 months, 20 patients (14 women, 6 Men) with 46 implants in the posterior mandible were available for clinical examination. The mean age was 49.3 years (SD 8.73, range between 36 and 65 years). Twenty-six implants were in the HGA group, and 20 implants were in the LGA group. The mean implant angulation with the occlusal plane was $85.20 \pm 0.83$ in the LGA group and $86.40 \pm 0.60$ in the HGA group (Table 1). No significant difference was found between these values. The mean overall marginal bone loss was $0.27 \pm 0.16 \mathrm{~mm}$ for the mesial side and $0.27 \pm 0.13 \mathrm{~mm}$ for the distal side in the LGA group (Table 1). The mean overall marginal bone loss (MBL) was $0.77 \pm 0.28 \mathrm{~mm}$ for the mesial side and 
$0.71 \pm 0.27 \mathrm{~mm}$ for the distal side in the HGA group (Table I). There was no significant difference in MBL for the mesial and distal side between the HGA and LGA group $(p>0.05)$.

Implant angulation with the occlusal plane had a significant negative moderate correlation with marginal bone resorption for the mesial side in the HGA group $(p=0.026, r=-0.436)$. However, this was not found significant for the LGA group $(p>0.05)$.

Table 1.

Comparison of the mean values of each parameter between the LGA and HGA groups (values shown as mean $\pm S D$ )

\begin{tabular}{|lccc|}
\hline & LGA group & HGA group & p value* \\
\hline Marginal bone resorption for mesial side & $0.27 \pm 0.16$ & $0.77 \pm 0.28$ & 0.134 \\
\hline Marginal bone resorption for distal side & $0.27 \pm 0.13$ & $0.71 \pm 0.27$ & 0.157 \\
\hline Implant angulation with occlusal plane & $85.2 \pm 0.83$ & $86.4 \pm 0.60$ & 0.236 \\
\hline
\end{tabular}

\section{DISCUSSION}

Bone resorption around the implant begins immediately after the loading of the prosthesis and continues to decrease until the prosthesis stabilizes. Some studies suggested that the reason for bone resorption could be caused by interruption of blood circulation due to external injury made during surgery. ${ }^{1}$ In addition, there were some studies stating various causes such as overload, biological width, the gap between the implant and the abutment. ${ }^{14}$ Systemic factors such as smoking, diabetes also affect bone resorption. In the literature, there are a limited number of studies investigating the effect of mandibular morphological features on residual bone loss in implants or conventional prostheses. ${ }^{12}$ In our study, we evaluated the role of low and high gonial angle on marginal bone resorption around the implant in cases with edentulous posterior mandible.

It was reported that in young adult individuals, the masseter and anterior temporal muscle exhibited strong activity during maximum biting due to a low gonial angle. ${ }^{15}$ Another study was stated that the masseter muscle of individuals having a high gonial angle is more anteriorly inclined when compared with individuals having low gonial angle. ${ }^{16}$ Patient having low gonial angle has more resorption when compared with patients having high gonial angle. ${ }^{12}$ Similar to these findings, Mercier $\mathrm{P}$ et al. ${ }^{17}$ reported that more residual bone resorption occurred in patients with low gonial angles than those with high gonial angles. In the previous study on 18 participants using an implant-retained overdentures study, it was found that there was a significant association between residual ridge resorption and gonial angle. In our study, we did not find any difference between HGA and LGA groups regarding marginal bone resorption around implant. Considering the resorption amounts in the HGA and LGA group, there were similar findings with the previous study. ${ }^{18}$

In many studies, it has been reported that many cofactors such as location and size of the implant, biological range, bone type, distribution of periimplant stress, implant angulation may be a factor in marginal bone resorption around the implant. In the meta-analysis made by Ata et al. ${ }^{19}$, it was reported that marginal bone loss was not significant between tilted and axial placed implants. Similar to this; Monje et al. evaluated by straight and angled implants from 25 degrees to 40 degrees, there was no difference in marginal bone resorption between flat and angled implants. ${ }^{20}$ The present study was found a correlation between the angulation of implant with the occlusal plane and marginal bone resorption in the HGA group. A possible explanation of this result was that direction of force produced by masseter muscle could be different from implant angulation with occlusal plane considering the previous report's result. ${ }^{16}$ This difference may have accumulated stress on the implant mesial side.

Limitation of this study, our sample size was small due to the elimination of many patients regarding exclusion and inclusion criteria of this retrospective study. Further studies having more sample sizes are needed.

\section{CONCLUSION}

Within the limitations of this study, a low gonial angle was not found as a risk factor alone regarding marginal bone resorption in our study. However, it is recommended that the implant angle should be adjusted as vertically as possible in patients having a high gonial angle.

This study was approved by the Medipol University ethical committee (Ethic no: 10840098-604.01.01E.1594). 


\section{REFERENCES}

1. Park J-H., Kim Y-K., Yun P-Y., Yi Y-J., Yeo I-S., Lee hyo-jung., et al. Analysis of factors affecting crestal bone loss around the implants. J Korean Dent Sci 2009;3:12-7.

2. Hermann JS., Cochran DL., Nummikoski P V., Buser D. Crestal Bone Changes Around Titanium Implants. A Radiographic Evaluation of Unloaded Nonsubmerged and Submerged Implants in the Canine Mandible. J Periodontol 1997; 68:1117-30.

3. Chung, D.M., Oh, T., Lee, J., Misch, C., \& Wang, $\mathrm{H}$. Factors affecting late implant bone loss: A retrospective analysis. J Prosthet Dent 2007; 22: 117-26

4. Albrektsson T, Buser D, Sennerby L. Crestal bone loss and oral implants. Clin Implant Dent Relat Res. 2012;14:783-791.

5. Howe MS., Keys W., Richards D. Long-term (10year) dental implant survival: A systematic review and sensitivity meta-analysis. J Dent 2019;84 :921

6. Sadowsky SJ. Occlusal overload with dental implants: a review. Int J Implant Dent 2019; 5:29

7. Johansson A., Omar R., Carlsson GE. Bruxism and prosthetic treatment: A critical review. J Prosthodont Res 2011;55:127-36

8. Fu J-H., Hsu Y-T., Wang H-L. Identifying occlusal overload and how to deal with it to avoid marginal bone loss around implants. Eur $\mathrm{J}$ Oral Implantol 2012;5:91-103

9. Van Spronsen PH., Koolstra JH., Van Ginkel FC., Weijs WA., Valk J., Prahl-Andersen B. Relationships between the orientation and moment arms of the human jaw muscles and normal craniofacial morphology. Eur $\mathrm{J}$ Orthod 1997; 19:313-28.

10. Ringqvist $M$. Isometric bite force and its relation to dimensions of the facial skeleton. Acta Odontol Scand 1973;31:35-42

11.Sassouni V. A classification of skeletal facial types. Am J Orthod 1969; 55:109-23

12.Ahmad R., Abu-Hassan M., Chen J., Li Q., Swain M. The Relationship of Mandibular Morphology with Residual Ridge Resorption Associated with Implant-Retained Overdentures. Int J Prosthodont 2016;29:573-580

13. Ogawa T., Osato S., Shishido Y., Okada M., Misaki K. Relationships between the gonial angle and mandibular ramus morphology in dentate subjects: A panoramic radiophotometric study. J Oral Implantol 2012;38:203-210

14. Qian J., Wennerberg A., Albrektsson T. Reasons for Marginal Bone Loss around Oral Implants. Clin Implant Dent Relat Res 2012;14:792-807
15.Moller E. The chewing apparatus. An electromyographic study of the action of the muscles of mastication and its correlation to facial morphology. Acta Physiol Scand Suppl 1966;280:1229.

16. Takada K., Lowe AA., Freund VK. Canonical correlations between masticatory muscle orientation and dentoskeletal morphology in children. Am J Orthod $1984 ; 86: 331-341$

17. Mercier P., Lafontant R. Residual alveolar ridge atrophy: Classification and influence of facial morphology. J Prosthet Dent $1979 ; 41: 90-100$

18.Calvo-Guirado JL., López-López PJ., Pérez-Albacete Martínez C., Javed F., Granero-Marín JM., Maté Sánchez de Val JE., et al. Peri-implant bone loss clinical and radiographic evaluation around rough neck and microthread implants: a 5-year study. Clin Oral Implants Res 2018;29:635-643.

19.Ata-Ali J., Peñarrocha-Oltra D., Candel-Marti E., Peñarrocha-Diago $M$. Oral rehabilitation with tilted dental implants: A metaanalysis. Med Oral Patol Oral Cir Bucal 2012;17:582-587

20. Monje A., Chan H-L., Suarez F., Galindo-Moreno P., Wang $\mathrm{H}$-L. Marginal bone loss around tilted implants in comparison to straight implants: a meta-analysis. Int J Oral Maxillofac Implants 2012;27:1576-83

Corresponding Author:

Emrah DILAVER

Istanbul Medipol University

Faculty of Dentistry

Department of Oral and Maxillofacial Surgery,

İstanbul, Turkey

Phone : +90 2124534942

E-mail : emrahdilaver@gmail.com 